НАУКОВИЙ ВІСНИК

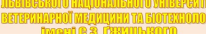

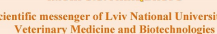

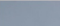
20. 311) MnN

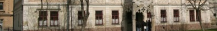

\section{Науковий вісник Яьвівського національного університету} ветеринарної медицини та біотехнодогій імені С.3. Гжицького.

Серія: Харчові технології

\author{
Scientific Messenger of Lviv National University \\ of Veterinary Medicine and Biotechnologies.
}

Series: Food Technologies

ISSN 2519-268X print

ISSN 2707-5885 online doi: $10.32718 /$ nvlvet-f9510

https://nvlvet.com.ua/index.php/food

UDC [ 664.887-026.613.1]:613.292: [543.635.4 : 633.521]

\title{
Development of technology of sauces with functional ingredients for restaurants
}

\author{
T. Lebedenko, G. Krusir, H. Shunko, H. Korkach \\ Odessa National Academy of Food Technologies, Odessa, Ukraine
}

Article info

Received 20.01.2021

Received in revised form 24.02.2021

Accepted 25.02.2021

Odessa National Academy of Food Technologies, Kanatna Str., 112, Odessa, 65039, Ukraine. Tel.: +38-097-909-91-77 E-mail:krussir.65@gmail.com
Lebedenko, T., Krusir, G., Shunko, H., \& Korkach, H. (2021). Development of technology of sauces with functional ingredients for restaurants. Scientific Messenger of Lviv National University of Veterinary Medicine and Biotechnologies. Series: Food Technologies, 23(95), 57-64. doi: $10.32718 /$ nvlvet-f9510

Currently, the creation of a range of new products that improve human nutritional status is a timely and urgent problem facing scientists in the food industry. In food technology it is effective to use functional ingredients that have enhanced protective and improved technological properties. It is possible to confidently attribute the components of plant origin, namely, dietary fiber and plant phospholipids, to such substances. Phospholipids are a group of essential substances that are irreplaceable and enter the human body only with food. Phospholipids cannot be formed independently in the human body, but perform important functions that have a positive effect on the body: they restore cell walls; they are involved in lipid metabolism, as well as reducing the risk of cholesterol formation; they actively participate in the delivery processes of biologically active substances to cells, etc. A rich source of biologically active substances are flax seeds, its medicinal properties have been known for centuries and are recognized by official medicine. The influence of flax seed mucilage and phospholipids in the formulation of red main sauce on rheological and physical parameters was investigated. Samples of sauces with replacement of 50 and $100 \%$ of flour for flax polysaccharides and $30 \%$ of animal fat for vegetable phospholipids were developed. The change of effective viscosity and density of the developed sauces is investigated. It was found that at a shear rate of $0.3333 s^{-1}$ the viscosity of the control sample is $14.32 \mathrm{~Pa} \cdot \mathrm{s}$, of the same one with the replacement of $50 \%$ flour and $10 \mathrm{~g}$ of fat and $100 \%$ flour and $10 \mathrm{~g}$ of fat, respectively, is 16.49 and $19.6 \mathrm{~Pa} \cdot \mathrm{s}$. This replacement in the experimental samples is accompanied by a slight increase in density. In order to substantiate the functional orientation of sauces in the introduction of herbal additives, studies were conducted to determine the antioxidant activity (AOA) of the developed sauces and their components. It was found that the maximum AOA a sauce with herbal additives has, which for 90 minutes is able to "quench" $89 \%$ of the radicals formed in these conditions in the model system. Adding sauces to ready meals, even in small quantities, help to increase the nutritional value and attractiveness of the consumed food. Therefore, the effect of additives on the consumer characteristics of sauces was investigated. It is established that the developed types of sauces have a characteristic structure, creamy and homogeneous consistency, pronounced taste and aroma. The conducted complex of researches allows to state with confidence that use of available vegetable raw materials instead of the ingredients possessing the raised food value, allows to reduce energy value and to expand the range of sauces of functional orientation for restaurant enterprises.

Key words: sauce, plant phospholipids, flax seed mucilage, rheological characteristics, effective viscosity, antioxidant activity, organoleptic properties.

\section{Розробка технології соусів з функціональними інгредіснтами для закладів ресторанного господарства}

\author{
Т. Є. Лебеденко, Г. В. Крусір, Г. С. Шунько, Г. В. Коркач
}

Одеська національна академія харчових технологій, м. Одеса, Украӥна

У даний час створення асортименту нових продуктів, щуо поліпшують харчовий статус людини, - своєчасна і нагальна проблема, яка стоїь перед вченими харчової промисловості. У харчових технологіях використовуються функціональні інгредієнти, 
які володіють підвищеними захисними і поліпшеними технологічними властивостями. Саме до таких речовин з впевненістю можна зарахувати компоненти рослинного походження, а саме харчові волокна та рослинні фосфоліпіди. Фосфоліпіди є групою незамінних есенціальних речовин, які в організм людини потрапляють тільки з їжею. Фосфоліпіди не можуть самостійно утворюватись в організмі людини, але виконують важливі функиії, які позитивно впливають на організм: відновлюють клітинні стінки; беруть участь у ліпідному обміні, а також у зниженні ризику утворення холестерину; активно беруть участь в проиесах доставки до клітин біологічно-активних речовин та ін. Багатим джерелом біологічно активних речовин є насіння льону, його лікувальні властивості відомі протягом століть і визнані офічійною медиииною. В роботі досліджено вплив слизу насіння льону і фосфоліпідів в рецептурі соусу червоного основного на реологічні та фізичні показники. Розроблені зразки соусів з заміною 50 та 100 \% борошна на полісахариди льону $і 30$ \% жиру тваринного на рослинні фосфоліпіди. Досліджено зміну ефективної в'язкості та густини розроблених соусів. Встановлено, шуо при швидкості зсуву 0,3333 c-1 в'язкість контрольного зразка становить 14,32 Па.с, зразка з заміною $50 \%$ борошна і 10 г жиру та $100 \%$ борошна $і 10$ г жиру відповідно 16,49 $і$ 19,6 Па·с. Така заміна у дослідних зразків супроводжується незначним підвищенням густини. 3 метою обтрунтування функиіональної спрямованості соусів при внесенні до їхнього складу рослинних добавок проведені дослідження щзодо визначення антиоксидантної активності (АОА) розроблених соусів та їх компонентів. Встановлено, щзо максимальною АОА володіє соус з рослинними добавками, який протягом 90 хв здатен “погасити” 89 \% радикалів, щчо утворилися в ичх умовах у модельній системі. Додавання соусів до готових страв навіть у незначних кількостях сприяє підвищенню харчової цінності і привабливості страв. Досліджено вплив добавок на споживчі характеристики соусів та встановлено, щзо розроблені види соусів мають характерну структуру, кремоподібну та однорідну консистенцію, яскраво виражений смак і аромат. Проведений комплекс досліджень дозволяє з впевненістю стверджувати, ицо використання доступної рослинної сировини замість інгредієнтів, щчо володіють підвищеною харчовою цінністю, дозволяє знизити енергетичну цінність і розширити асортимент соусів функціональної спрямованості для підприємств ресторанного господарства.

Ключові слова: соус, рослинні фосфоліпіди, слизи насіння льону, реологічні характеристики, ефективна в'язкість, антиоксиданта активність, органолептичні властивості.

\section{Вступ}

Нині харчування є одним з основних факторів, що визначають здоров’я і активність людини, іiї нормальне зростання і розвиток, працездатність, тривалість життя, резистентність організму до захворювань і шкідливих факторів навколишнього середовища. Проблема раціонального харчування населення має величезне соціальне значення і відіграє вирішальну роль у забезпеченні якості та тривалості життя людини, їі здоров’я. В Україні найважливішими порушеннями в системі харчування $є$ надмірне споживання тваринних жирів, вуглеводів, на тлі дефіциту повноцінних білків тваринного походження, поліненасичених жирних кислот, мікроелементів, вітамінів і харчових волокон. Тому перед науковцями стоїть завдання - створення асортименту нових продуктів, що мають функціональну спрямованість і поліпшують харчовий статус людини.

Актуальність теми. У харчовій технології ефективним напрямком $€$ використання функціональних інгредієнтів, що володіють підвищеними фізіологічними і поліпшеними технологічними властивостями. 3 цієї точки зору величезний потенціал у рослинної сировини, яка $є$ невичерпним джерелом натуральних біологічно активних речовин з різнобічними функціонально-фізіологічними властивостями (Lovkova et al., 2001; Formazjuk, 2003; Ollinyk et al., 2020). Функціональні продукти харчування, що містять компоненти рослинної сировини, сьогодні визнані ефективним засобом у профілактиці широкого спектру захворювань, важливою складовою при їх лікуванні (Antipova \& Martel'janova, 2013; Kurchaeva et al., 2014; Iorgacheva \& Lebedenko, 2014; Veretnova, 2015; Jeske et al., 2018; Putnik et al., 2018; Lourenço et al., 2019).

Для меню сучасних ресторанів потрібні страви 3 рослинної сировини, які були би безпечними, натуральними і смачними та, що дуже важливо, збагаченими фізіологічними інгредієнтами. Найбільш перспективними для збагачення є вироби і страви, з яких складається повсякденний раціон харчування. Особливу групу серед них являють собою соуси. Соус (з фр. sauce - підлива) - це гаряча або холодна пряна рідина різної консистенції, що подається зі стравою для надання іiі особливого смаку, а також як добавка при приготуванні харчових продуктів. Соуси $€$ невід'ємною частиною більшості страв, які готуються 3 різноманітних продуктів. Вони надають стравам соковитості, особливого смаку й аромату, привабливого вигляду. Їх аромат і смак збуджують апетит, вони сприяють кращому засвоєнню основних компонентів страви завдяки наявності екстрактивних, ароматичних і смакових речовин, які збуджують секрецію травних залоз. Соуси також здатні збагатити основну страву дефіцитними нутрієнтами: макро-, мікроелементами, вітамінами, харчовими волокнами, ПНЖК та іншими біологічно активними речовинами. Отже, соуси здатні показати в новому світлі звичні страви, продукти та інгредієнти - словом, вони є важливим компонентом страв будь-якої кухні.

Сьогодні в ресторанах використовують безліч різновидів соусів: гарячі та холодні, рибні, м'ясні, гострі, молочні, сирні, десертні, низькокалорійні - овочеві, ягідні та масляні. В багатьох ресторанах розробляють спеціальні соусні карти, в які включають соуси для кожної категорії страв. Однак недостатньо уваги приділяється розробці нових рецептур і технологій кулінарних виробів для здорового харчування, у тому числі й соусів, які є невід'ємною частиною щоденного раціону людини.

У роботах українських вчених розглянуто і запропоновано наукові підходи щодо розроблення різних видів соусів 3 додаванням до їх складу різноманітних функціональних інгредієнтів. Так, Кублінська I. А. розробила технологію соусу грибного 3 використанням порошків з печериць, рейші, шиїтаке та соуси грибні зі згущувачем, що дозволяе підвищити біологічну цінність продукту та розширити асортимент соусної продукції на рослинній сировині для закладів ресторанного господарства (Kublinska, 2018).

Вчені Чоні І. В. та Суткович Т. Ю. вищого навчального закладу Укоопспілки “Полтавський універси- 
тет економіки і торгівлі” запропонували технологію соусів емульсійного типу із застосуванням борошна вівсяної та перлової круп як емульгаторів і стабілізаторів (Choni \& Sutkovych, 2015).

Фахівцями Харківського державного університету харчування та торгівлі Погожих М. І., Головко Т. М., Дьяковим О. Г. (Pohozhykh et al., 2016) досліджено внесення до майонезу "Провансаль" та соусу білого основного порошкоподібних дієтичних добавок на основі хелатних комплексів. Одержано соуси, які збагачені незамінними мікронутрієнтами із традиційними показниками якості.

Науковцями Слащевою А. В., Поповою С. Ю., Клименко А. B. (Slashcheva et al., 2017) запропоновано для приготування соусів використовувати пюре 3 гарбуза та плодів обліпихи і показано високі органолептичні показники отриманих соусів, доведено їх безпечність та підвищений вміст пектину, каротиноїдів, аскорбінової кислоти та мінеральних речовин. Відомі також розробки технології виробництва низьколактозних емульсійних соусів 3 використанням напівфабрикату зі згущеної молочної сироватки та ферментованого пюре 3 м'якоті гарбуза. Отримані соуси мають високу харчову та біологічну цінність, підвищений вміст білкових речовин, а також збалансований амінокислотний i покращений вітамінномінеральний склад (Hnitsevych \& Honchar, 2019).

Також вирішенню даної проблеми присвячено низку робіт зарубіжних вчених (Hernández-Carrión et al., 2015; Shalaby et al., 2017; de Araujo et al., 2020). У роботі (de Araujo et al., 2020) досліджено введення у томатний соус як загущувача i емульгатора слизу бамії в натуральній та ліофілізованій формах. У розроблених видах соусу міститься значна кількість фенольних сполук і вони мають високу антиоксидантну активність, покращені споживчі властивості та сенсорні характеристики. Група дослідників (Shalaby et al., 2017) розробила новий вид натурального соусу iз плавленого сиру, приправленого ефірними маслами. Ефірні масла надають одержаному соусу антиоксидантні та антимікробні властивості, мають відмінний смак і гарний колір. Вчені з Іспанії запропонували збагатити білі соуси червоним солодким перцем, виходячи 3 його властивостей - джерела антиоксидантних сполук. У роботі проведено дослідження щодо вивчення впливу добавки червоного перцю і модифікованого крохмалю на реологічні показники, мікроструктуру, колір. Визначені сенсорні характеристики та споживча прийнятність нових білих соусів (Hernández-Carrión et al., 2015).

Однак бракує досліджень щодо розроблення рецептур соусів з розчинними харчовими волокнами, які сприяють зв’язуванню і виведенню $з$ організму антропогенних забруднювачів і продуктів порушення процесів метаболізму речовин. Харчові волокна належать до однієї з найнеобхідніших категорій компонентів продуктів харчування. Вони визнані могутнім інструментом у профілактиці і комплексному лікуванні численних "хвороб століття", зокрема таких грізних, як цукровий діабет, низка пухлинних захворювань, атеросклероз, ішемічна хвороба серця.
В роботі запропоновано використовувати водорозчинні полісахариди насіння льону або слизи, які складаються 3 двох типів полісахаридів - нейтральних арабіноксиланів і кислих пектиноподібних речовин. Клеєподібна консистенція слизів дозволяє використовувати їх як харчові добавки з різноманітними функціональними властивостями - структуроутворювачів, емульгаторів, стабілізаторів, водоутримуючих гідроколоїдів.

Також в умовах погіршення екологічної обстановки і структури харчування особливий інтерес викликають речовини антиоксидантної і ліпотропної дії. Важливим джерелом цих речовин у харчуванні можуть служити фосфоліпіди рослинного походження.

Таким чином, розробка технології червоного соусу, що володіє детоксикуючими властивостями, а також ліпотропною і антиоксидантною діями, є доцільним і актуальним.

Метою роботи є розробка соусу червоного збагаченого профілактичної спрямованості на основі рослинної сировини.

Відповідно до поставленої мети необхідно вирішити такі завдання:

- вибір i обгрунтування функціональних інгредієнтів для збагачення соусу червоного основного;

- дослідження структурно-механічних властивостей соусу з рослинними добавками;

- вивчення антиоксидантної активності розроблених соусів та їх компонентів;

- дослідження споживчих характеристик дослідних зразків соусу.

\section{Матеріал і методи досліджень}

Експериментальна частина роботи виконана в Одеській національній академії харчових технологій.

Дослідження включали заміну борошна пшеничного на слизи насіння льону та заміну жиру тваринного на рослинні фосфоліпіди в рецептурі соусу червоного основного.

Сировина, яка використовувалась для досліджень, відповідала ДСТУ та вимогам діючої в Україні нормативної документації.

Відбір проб готового продукту та підготовка проб до аналізу здійснювалися за стандартною методикою.

Вивчення реологічних характеристик проводили на ротаційному віскозиметрі "Реотест-2" (HernándezCarrión et al., 2015). При дослідженні соусів швидкість зсуву змінювалась - 0,3333-145,8 $\mathrm{c}^{-1}$.

Густина соусів визначалась за допомогою пікнометра (Iorhachova et al., 2011).

Визначення органолептичних показників якості продукту здійснювалося за допомогою профільного аналізу (описового аналітичного методу) (Yalçı̈öz \& Erçelebi, 2016).

Антиоксидантну активність (АОА) визначали модифікованим тіоцинатним методом 3 неспецифічним субстратом окиснення (1,3\% розчин оливкового масла в $96 \%$ етиловому спирті) (Sal'kova \& Amzashvili, 1987).

Реакційна суміш складалася 3 0,5 мл оливкової оліі, 1 мл 0,05 M Na-фосфатного буфера pH 7 і дослі- 
джуваного зразка. Реакційну суміш нагрівали на водяній бані протягом 1,5 год. Після охолоджування реакційної суміші додавали 0,1 мл $30 \%$ роданового амонія $\mathrm{NH}_{4}(\mathrm{CNS})$ і 0,1 мл $0,02 \mathrm{M} \mathrm{FeSO}_{4} \cdot 7 \mathrm{H}_{2} \mathrm{O}$, заздалегідь очищеного від іонів $\mathrm{Fe}^{3+}$ перекристалізацією 3 $96 \%$ спирту. Інтенсивність розвинутого червоного забарвлення вимірювали спектрофотометрично при довжині хвилі 540 нм на спектрофотометрі.

Суть методу така: у субстраті окиснення ініціюють утворення пероксидних сполук, кількість яких фіксували реакцією з утворенням комплексної сполуки, що має максимум поглинання при довжині хвилі 500...540 нм. При введенні в модельну систему інгібітору окиснення (досліджувані зразки соусу) кількість пероксидних сполук знижується, що супроводжується зміною інтенсивності забарвлення комплексної сполуки: іон $\mathrm{Fe}^{2+}$ перекисними і гідроперекисними радикалами окиснюється в іон $\mathrm{Fe}^{3+}$, який при взаємодії 3 CNS- утворює комплексну сполуку, забарвлену в червоний колір. Антиоксидантну активність визначали за формулою:

$$
A O A=\frac{[R 1]-[R 2]}{[R 1]} \cdot 100, \%
$$

де $[R 1]$ - концентрація пероксидних сполук в модельній системі без антиокислювача, відн. од. оптич. щільності;

$[R 2]$ - концентрація пероксидних сполук в модельній системі 3 антиокислювачем, відн. од. оптич. щільності.

Дослідження проведені в трикратному повторюванні.

\section{Результати та їх обговорення}

Соуси поряд 3 цілою низкою переваг також здатні збагатити основну страву дефіцитними нутрієнтами: макро-, мікроелементами, вітамінами, харчовими волокнами, ПНЖК та іншими біологічно активними речовинами, можуть посилити детоксикайційну, антиоксидантну активність раціону, впливати на роботу шлунково-кишкового тракту. Тому доцільним буде розробити рецептури соусів з використанням рослинної сировини з заданими функціональнотехнологічними властивостями. При створенні нових композицій соусів важливим є вибір і обгрунтування рецептурних інгредієнтів, їх раціональне комбінування, що забезпечить отримання напівфабрикатів і соусів 3 необхідними структурно-механічними та органолептичними властивостями, заданою фізіологічною дією.

Як основу для композиції прийняли рецептуру соусу червоного основного № 1.365 (Shalimov et al., 2000). Для приготування соусу використовують коричневий бульйон, пасероване і розведене бульйоном борошно, пасеровані овочі (ріпчасту цибулю, моркву, петрушку) з томатним пюре, а також жир тваринний топлений. Соус основний червоний використовують для приготування похідних соусів і самостійно. Основний червоний соус подають до страв із натурального та котлетного м'яса, до шинки, сосисок; різнови- ди червоного соусу до смажених м'ясних страв. Багато соусів використовують для тушкування м'яса i овочів. На основі даного соусу готують цибулевий соус, соус червоний з цибулею і огірками, соус червоний $з$ вином, соус $з$ цибулею і грибами, соус червоний кисло-солодкий та широкий асортимент фірмових соусів, які розробляються у ресторанах.

Якість готового соусу з заданими функціональними властивостями значною мірою залежить від використаних інгредієнтів, які вводять до рецептури.

Традиційно під час приготування соусів як загусник (емульгатор і стабілізатор) використовують борошно пшеничне вищого сорту. Однак таке борошно має занижену харчову цінність, тому доцільно для збагачення виробу харчовими волокнами внести добавку зі слизів насіння льону, замінюючи при цьому борошно пшеничне. У роботі досліджували введення біологічно-активної добавки (БАД) “Ентерос" 3 насіння льону, хімічний склад якої представлений геміцелюлозами $(80 \ldots 83 \%), \quad$ білковою складовою $(4,0 \ldots 5,2 \%)$ і мінеральними речовинами $(1,5 \ldots 2,5 \%)$. Також вносили рослинні фосфоліпіди для часткової заміни жиру тваринного в рецептурі.

У роботі досліджували зразки соусу з заміною $50 \%$ i $100 \%$ борошна на полісахариди льону та 3 заміною 10 г тваринного жиру на рослинні фосфоліпіди. Досліджували такі зразки соусів:

1. Соус червоний основний - контроль;

2. Соус червоний з заміною $50 \%$ борошна і 10 г жиру;

3. Соус червоний з заміною $100 \%$ борошна і 10 г жиру;

Щоб отримати готовий виріб високої якості, необхідно вирішити питання про одержання соусу стабільної та однорідної консистенції, який би при подачі не розшаровувався. Тому доцільно дослідити зміну в'язкості соусів з внесенням добавок.

Однією з найважливіших характеристик структурно-механічних властивостей соусів, що визначає їх реологічний стан, є їхня в'язкість. В'язкість (ๆ) визначає стан матеріалу і $є$ мірою опору течії (внутрішнє тертя). Експериментальне визначення в'язкості досліджуваних соусів проводилося на ротаційному віскозиметрі “Реотест-2". Випробування проводилися за допомогою вимірювальної системи циліндрів Н/Н. Мірний бачок заповнювали досліджуваним продуктом і темперували при температурі $50{ }^{\circ} \mathrm{C}$.

Результати досліджень щодо зміни ефективної в'язкості соусів від градієнта швидкості зсуву при різній заміні борошна і жиру тваринного наведені на рис. 1.

Як свідчать експериментальні дані, при температурі $50{ }^{\circ} \mathrm{C}$ найбільшою в'язкістю володіє соус 3 повною заміною борошна на структуроутворювач полісахаридної природи, найменшою - контрольний зразок. Так, при швидкості зсуву $0,3333 \mathrm{c}^{-1}$ в'язкість контрольного зразку становить 14,32 Па с, зразка з заміною $50 \%$ борошна і 10 г жиру та $100 \%$ борошна і 10 г жиру відповідно 16,49 і 19,6 Па·с. Отже, можна констатувати, що соус з повною заміною борошна на рослинні полісахариди має густішу, більш в'язку консистенцію, що впливає на органолептичні властивості, 
порівняно з контрольним зразком. Підвищення ефективної в’язкості у зразках з заміною борошна обумов- лено тим, що при внесенні добавки слизів льону до складу соусів вносяться розчинні полісахариди.

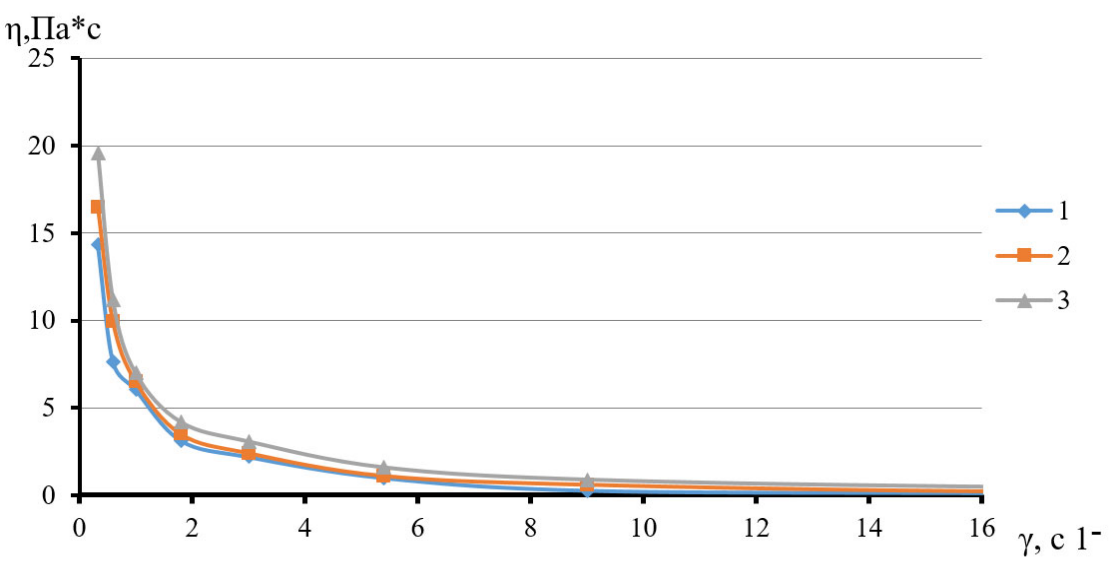

Рис. 1. Залежність ефективної в'язкості соусів від градієнта швидкості зсуву при температурі $50{ }^{\circ} \mathrm{C}$ : 1 - контроль; 2 - з заміною 50 \% борошна і 10 г жиру; 3 - з заміною 100 \% борошна і 10 г жиру

При оформленні та подачі страв із соусами велике значення має їхня густина. Дуже густі соуси не дають соковитості, нерівномірно розподіляються по поверхні страви, що ускладнює їх використання при оформленні та погіршує зовнішній вигляд готової страви.
Занадто рідкі соуси здатні негативно впливати на основну страву, головним чином розм'якшуючи його, а також розтікатися по поверхні, при цьому втрачається первісна форма. Тому важливо дослідити вплив добавок на густину соусів (рис. 2).

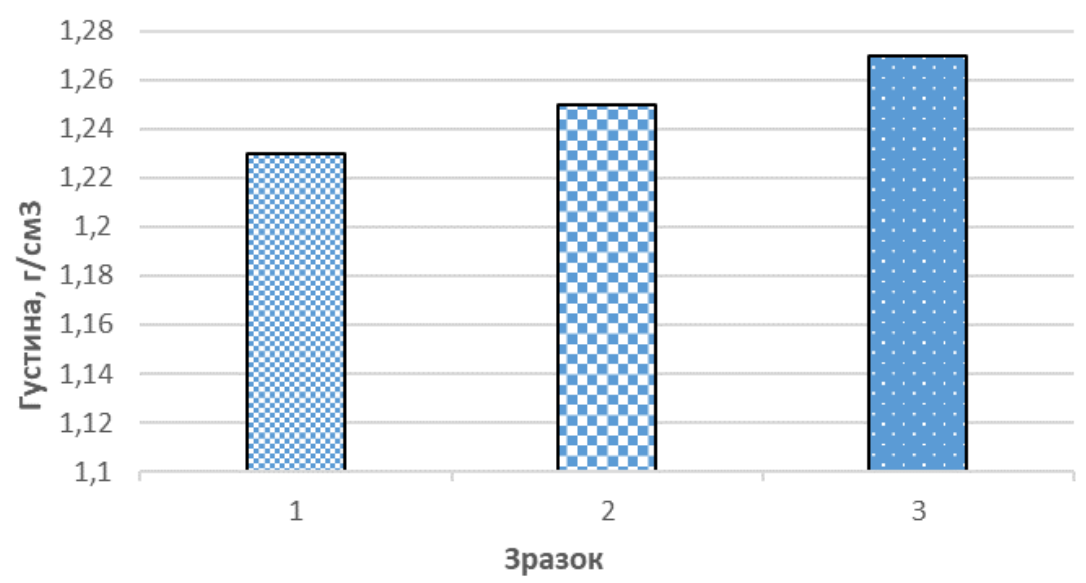

Рис. 2. Залежність густини соусів від маси добавки: 1 - контроль; 2 - з заміною 50 \% борошна і 10 г жиру; 3 - з заміною $100 \%$ борошна і 10 г жиру

Аналіз експериментальних даних показав, що при заміні борошна на слизи льону відбувається незначне збільшення густини соусів. При заміні 50 \% борошна

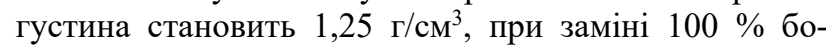
рошна $-1,27 \Gamma / \mathrm{cm}^{3}$. Таким чином, при заміні борошна на рослинні полісахариди відбувається незначне збільшення густини, що не позначається на якості отриманих соусів. Розроблені соуси мають відмінні структурно-механічні та органолептичні показники.

Нашим завдання було максимальне збагачення готового продукту функціональними інгредієнтами. Тому надалі як соус функціональної спрямованості використовувався зразок з $100 \%$ заміною борошна на слизи льону та заміною $40 \%$ тваринного жиру на лецитин.

Для обгрунтування функціональної спрямованості соусів 3 рослинними інгредієнтами необхідно до- слідити антиоксидантну активність отриманих соусів. Під антиоксидантною активністю розуміють здатність речовин гальмувати або обривати утворення ланцюгів у вільнорадикальних реакціях окиснення. Тобто здатність протистояти оксидативному стресу в організмі сучасної людини, який набуває поширення через часті стреси, перевтому, забруднення навколишнього середовища, шкідливі звички і т. ін.

Антиоксидантну активність (АОА) досліджуваного соусу, а також його окремих компонентів визначали модифікованим тіоцианатним методом 3 неспецифічним субстратом (1,3\% розчин оливкової олії в $96 \%$ розчині етилового спирту). Значення антиоксидантної активності соусів та рослинних добавок наведені на рис. 3. 


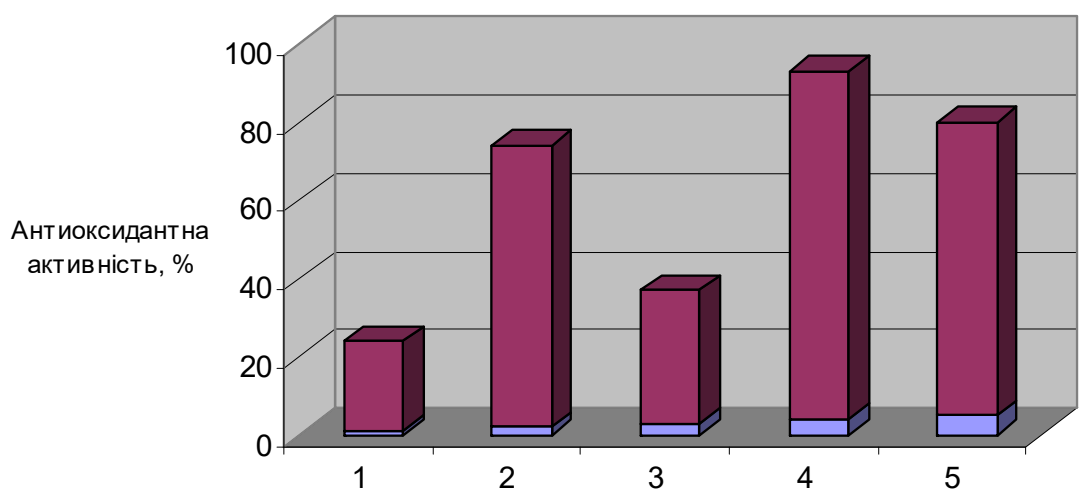

Рис. 3. Антиоксидантна активність досліджуваних систем: 1 - традиційний соус (контроль - 23 \%); 2 - лецитин (72 \%); 3 - слизи (34 \%); 4 - соус функціонального призначення (89 \%); 5 - механічна суміш лецитин + слизи (75 \%)

Як свідчать експериментальні результати, максимальною АОА володіє соус з рослинними добавками. Так, при $t=90{ }^{\circ} \mathrm{C}$ протягом 90 хв його основні компоненти здатні “погасити” 89 \% радикалів, що утворились в цих умовах у модельній системі. Мінімальну AOA в цих же умовах виявили зразки традиційного соусу червоного основного та слизи.

Встановлено, що найбільш істотний синергічний ефект щодо інгібування процесів окиснення проявляє соус функціонального призначення, що, ймовірно, пояснюється тим, що один 3 інгібіторів обриває ланцюги окиснення, а інший - руйнує пероксиди.

Оскільки соуси значно впливають на органолептичні показники страв, то важливим завданням $€$ визначити вплив добавок на споживчі властивості розроблених соусів.

Таблиця 1

Органолептичні показники дослідних зразків соусу

\begin{tabular}{|c|c|c|c|}
\hline Показники & Контроль & $\begin{array}{c}\text { Cоус } 3 \text { заміною } 50 \% \\
\text { борошна }\end{array}$ & $\begin{array}{c}\text { Соус з заміною } 100 \% \\
\text { борошна }\end{array}$ \\
\hline Зовнішній вигляд & $\begin{array}{c}\text { Однорідна маса, без плівок, спо- } \\
\text { стерігається незначне відділення } \\
\text { жирових крапель на поверхні, } 3 \\
\text { окремими грудочками пасерова- } \\
\text { ного борошна }\end{array}$ & $\begin{array}{c}\text { Однорідна маса без плівок і } \\
\text { жиру на поверхні }\end{array}$ & $\begin{array}{c}\text { Однорідна маса без плівок і } \\
\text { жиру на поверхні }\end{array}$ \\
\hline Консистенція & Пастоподібна, злегка в'язка & $\begin{array}{c}\text { Густа консистенція, кремо- } \\
\text { подібний продукт, од- } \\
\text { норідний за консистенцією }\end{array}$ & $\begin{array}{c}\text { Густа консистенція, кремо- } \\
\text { подібний продукт, од- } \\
\text { норідний за консистенцією }\end{array}$ \\
\hline Колір & & Темно-червоний & \\
\hline Смак, запах & $\begin{array}{c}\text { Властивий даному виду } \\
\text { напівфабрикату, запах і смак } \\
\text { томатів і бульйону виражені } \\
\text { нечітко }\end{array}$ & $\begin{array}{c}\text { властивий даному виду } \\
\text { напівфабрикату, без сторон- } \\
\text { нього присмаку та запаху }\end{array}$ & $\begin{array}{c}\text { властивий даному виду } \\
\text { напівфабрикату, без сторон- } \\
\text { нього присмаку та запаху, } \\
\text { смак і аромат добре виражені }\end{array}$ \\
\hline
\end{tabular}

Органолептична оцінка зразків соусів (контрольного i дослідного) проводилася дегустаційною комісією за бальною системою. За зовнішнім виглядом, консистенцією, кольором, смаком і запахом виставлялися бали, де 5 балів відповідало найвищій оцінці, 2 бали - найнижчій. Результати
Соуси за органолептичними показниками повинні відповідати вимогам відповідних стандартів. При оцінці органолептичних показників соуси оцінюють за такими показниками: зовнішній вигляд (у тому числі й за кольором), консистенція, запах і смак.

Зовнішній вигляд соусів - загальне зорове враження, яке на практиці має вирішальне фізіологічне i психологічне значення. Соуси повинні мати вигляд однорідної маси, без плівок і жирних речовин не поверхні. Неоднорідна консистенція погіршує зовнішній вигляд страв і знижує смакові якості їжі, а поява плівок і жиру на поверхні негативно впливає на смак страви.

Органолептичні показники розроблених рецептур соусів наведено в табл. 1. органолептичної оцінки зразків соусів наведено на рис. 4.

Для контрольного зразка соусу червоного бали знижено за зовнішній вигляд, оскільки було виявлено наявність грудочок завареного борошна, спостерігалося деяке відділення крапельок жиру на поверхні. 


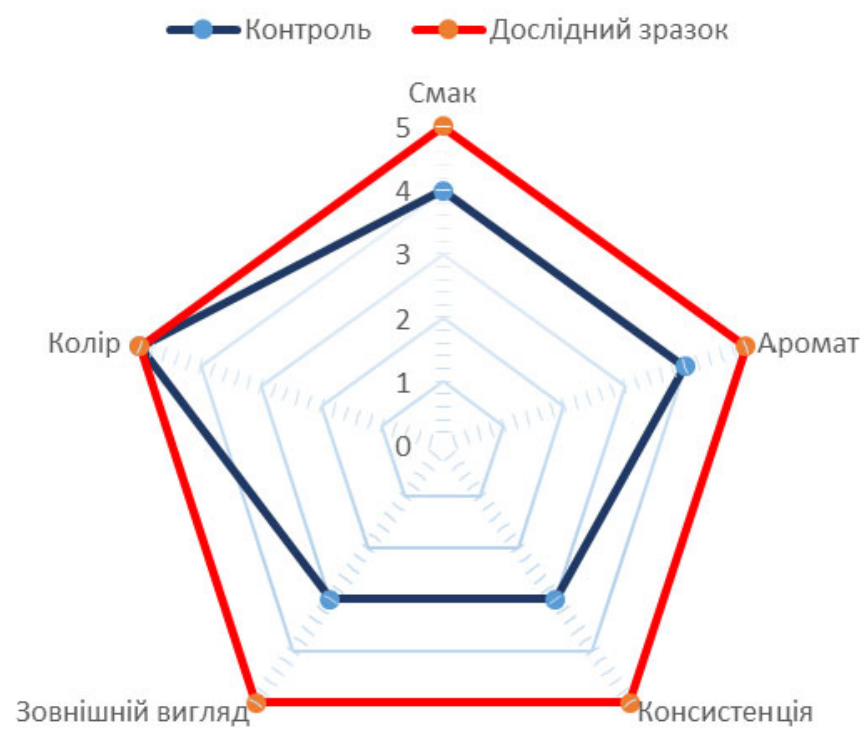

Рис. 4. Профілограма соусів

Консистенція контролю поступалася дослідним зразкам, вона характеризувалася як дещо в'язка, клейка. Це зумовлено використанням борошна як загущувача, особливостями його функціональнотехнологічних властивостей. Використання ж композиції зі слизів (полісахаридів) льону та лецитину, які виявляють властивості загущувача та емульгатора, призводить до утворення густої, кремоподібної маси.

\section{Висновки}

Результати проведених досліджень свідчать, що функціональні інгредієнти - слизи борошна льону та рослинні фосфоліпіди - перспективно та доцільно використовувати в рецептурі соусу червоного. У роботі встановлено, що введення слизу насіння льону дозволяє виключити із рецептури $100 \%$ борошна пшеничного, а рослинних фосфоліпідів - 40 \% жиру тваринного.

При цьому одержали соус, який володіє не тільки відмінними органолептичними характеристиками: характерною структурою, яскраво вираженим смаком i ароматом, кремоподібною консистенцією, а й функціональними властивостями - підвищився вміст харчових волокон і фосфоліпідів рослинного походження, також розроблений вид соусу здатний позитивно впливати на фізіологічні процеси організму людини. А саме: володіє детоксикуючими властивостями і має антиоксидантну та ліпотропну активність.

Таким чином, введення до складу соусу червоного харчових волокон та рослинних фосфоліпідів дозволить значно розширити асортимент соусів та страв 3 функціональними властивостями на підприємствах ресторанного господарства, буде цікавим для виробників безглютенової продукції, а також для відвідувачів 3 несприйняттям складових пшеничного борошна.

\section{References}

Antipova, L. V., \& Martel'janova, L. E. (2013). Ocenka potenciala istochnikov rastitel'nyh belkov dlja proizvodstva produktov pitanija. Pishhevaja promyshlennost', 8, 10-12. URL: https://cyberleninka.ru/article/n/otsenkapotentsiala-istochnikov-rastitelnyh-belkov-dlyaproizvodstva-produktov-pitaniya/viewer (in Russian).

Choni, I. V., \& Sutkovych, T. Iu. (2015). Vykorystannia pryrodnykh stabilizatoriv $\mathrm{u}$ tekhnolohii emulsiinoi produ-ktsii. Naukovyi visnyk Poltavskoho universytetu ekonomiky i torhivli, 1(73), 54-59. URL: https://journals.indexcopernicus.com/api/file/viewByF ileId/171666.pdf (in Ukrainian).

de Araujo, S. S. F. P., da Silva, L. M. A., Feitosa, B. F., da Silva, A. L., \& Cavalcanti, M. T. (2020). Okra mucilage Abelmoschus esculentus (L.) Moench as a natural additive in tomato sauce. Agrarian and Biological Sciences, 9(5), 1-17. doi: 10.33448/rsdv9i5.2707.

Formazjuk, V. I. (2003). Jenciklopedija pishhevyh lekarstvennyh rastenij: Kul'turnye i dikorastushhie rastenija $\mathrm{v}$ prakticheskoj medicine. Izd-vo A.S.K. (in Russian).

Hernández-Carrión, M., Sanz, T., Hernando, I., Llorca, E., Fiszman, S. M., \& Quiles, A. (2015). New formulations of functional white sauces enriched with red sweet pepper: a rheological, microstructural and sensory study. European Food Research and Technology, 240, 1187-1202. doi: 10.1007/s00217-015-2422-1.

Hnitsevych, V., \& Honchar, Yu. (2019). Tekhnolohiia ta yakist nyzkolaktoznykh emulsiinykh sousiv. Tovary i rynky, 3, 94-101. doi: 10.31617/tr.knute.2019(31)09 (in Ukrainian).

Iorgacheva, E. G., \& Lebedenko, T. E. (2014). Potencial lekarstvennyh, prjano-aromaticheskih rastenij $\mathrm{V}$ povyshenii kachestva pshenichnogo hleba. Vostochno-Evropejskij zhurnal peredovyh tehnologij, 2(12), 101-108. URL: http://nbuv.gov.ua/UJRN/ Vejpte_2014_2\%2812\%29_20 (in Russian). 
Iorhachova, K. H., Makarova, O. V., Hordiienko, L. V., \& Korkach, H. V. (2011). Tekhnolohiia kondyterskoho vyrob-nytstva. Praktykum: navch. posibnyk. Odesa: ONAKhT (in Ukrainian).

Jeske, S., Zannini, E., \& Arendt, E. K. (2018). Past, present and future: The strength of plant-based dairy substitutes based on gluten-free raw materials. Food research international (Ottawa, Ont.), 110, 42-51. doi: 10.1016/j.foodres.2017.03.045.

Kublinska, I. A. (2018). Rozrobka tekhnolohii sousu hrybnoho $\mathrm{z}$ funktsionalnymy inhrediientamy. Tekhnolohichnyi audyt ta rezervy vyrobnytstva, 4(3), 28-34 (in Ukrainian).

Kurchaeva, E. E., Hodykina, O. A., Kislaja, V. V., \& Ljutikova, A. O. (2014). Ispol'zovanie potenciala rastite-l'nogo syr'ja $\mathrm{V}$ proizvodstve funkcional'nyh kompozitov dlja mjasnyh sistem. Sovremennye naukoemkie tehnologii, 5(1), 188. URL: https://toptechnologies.ru/ru/article/view?id=33828 (in Russian).

Lourenço, S. C., Moldão-Martinsand, M., \& Alves, V. D. (2019). Antioxidants of natural plant origins: from sources to food industry applications. Molecules, 24, 4132. doi: 10.3390/molecules24224132.

Lovkova, M. Ja., Buzik, G. N., Sokolova, S. M., \& Kliment'eva, N. I. (2001). Osobennosti himizma lekarstvennyh rastenij (obzor). Prikladnaja biohimija i mikrobiologija, 37(3), 261-273 (in Russian).

Ollinyk, P., Voronenko, D., \& Lysiuk, R. (2020). Radioprotective properties of polyphenolic compounds of edible and aromatic plants. Kharchova nauka i tekhnolohiia, 14(3), 62-72. URL: https://cardfile.onaft.edu.ua/jspui/handle/123456789/16759?local $\mathrm{e}=$ en.

Pohozhykh, M. I., Holovko, T. M., \& Diakov, O. H. (2016). Rozrobka tekhnolohii zbahachennia sousiv emulsiinoho typu diietychnymy dobavkamy. Naukovyi visnyk Poltavskoho universytetu ekonomiky i torhivli, 1(78), 37-44 (in Ukrainian).
Putnik, P., Lorenzo, J. M., Barba, F. J., Roohinejad, S., Režek Jambrak, A., Granato, D., Montesano, D., \& Bursać Kovačević, D. (2018). Novel food processing and extraction technologies of high-added value compounds from plant materials. Foods, 7(7), 106. doi: 10.3390/foods7070106.

Sal'kova, E. G., \& Amzashvili, M. G. (1987). Izuchenie antioksidantnoj aktivnosti jekstraktov kutikuly jablok. Prikladnaja biohimija i mikrobiologija, 23(5), 686691 (in Russian).

Shalaby, S. M., Mohamed, A. G., \& Bayoumi, H. M. (2017). Preparation of a novel processed cheese sauce flavored with essential oils. International Journal of Dairy Science, 12, 161-169. doi: 10.3923/ijds.2017.161.169.

Shalimov, O. V., Diachenko, T. P., \& Kravchenko, L. O. (2000). Zbirnyk retseptur natsionalnykh strav i kulinarnykh vyrobiv: Dlia pidpryiemstv hromad. kharchuvannia vsikh form vlasnosti. K. A.S.K. (in Ukrainian).

Slashcheva, A. V., Popova, S. Iu., \& Klymenko, A. V. (2017) Doslidzhennia pokaznykiv yakosti ta bezpechnosti sousiv $\mathrm{z}$ pidvyshchenym vmistom pektynovykh rechovyn. Obladnannia ta tekhnolohii kharchovykh vyrobnytstv, 35, 18-24 (in Ukrainian).

Veretnova, O. Ju. (2015). Vozmozhnosti ispol'zovanija netradicionnogo rastitel'nogo syr'ja $\mathrm{v}$ proizvodstve pishhevyh produktov funkcional'nogo naznachenija. Vestnik KrasGAU, 6, 154-158. URL: https:/cyberleninka.ru/article/n/vozmozhnostiispolzovaniya-netraditsionnogo-rastitelnogo-syrya-vproizvodstve-pischevyh-produktov-funktsionalnogonaznacheniya/viewer (in Russian).

Yalçınöz, S. K., \& Erçelebi, E. (2016). Rheological and sensory properties of red colored fruit sauces prepared with different hydrocolloids. Journal of International Scientific Publications: Agriculture \& Food, 4(1), 496-509. 